\title{
INCREASING THE EFFICIENCY OF COMBINED CONTROL OF THE ROCKET ENGINE THRUST VECTOR
}

\author{
Institute of Technical Mechanics \\ of the National Academy of Sciences of Ukraine and the State Space Agency of Ukraine, \\ 15 Leshko-Popel St., Dnipro 49005, Ukraine; e-mail: sinatal@ukr.net
}

Solving new problems of rocket space stage control calls for improving rocked engine thrust vector control actuators in order to reduce energy consumption for control, simplify their design, and improve their dynamic performance and reliability.

As a result of previous studies, in which the authors of this work took part, a new bifunctional thrust vector control system based on a combination of a mechanical and a gas-dynamic thrust vector control system was proposed and substantiated. That solution on thrust vector control improvement made it possible to realize the advantages of the constituent subsystems, while eliminating their disadvantages.

This paper focuses on the drawback of the new concept of thrust vector control, which consists in the need for heavy-mass drives to rotate engine components.

The paper presents and substantiates a new solution on eliminating the above drawback by transferring the function of the rotary drives to the gas-dynamic system.

In doing so, the large force that rotates the engine on the hinge is produced by the gas-dynamic system in a pulsed mode, thus eliminating large energy consumption (during the operation of the gas-dynamic system) for engine rotation. The rocket stage is stabilized by control forces of small amplitude and high frequency produced by the gas-dynamic control system. So the bifunctional thrust vector control system is transformed into a system that is entirely gas-dynamic, except that a hinge joint is used to rotate engine components (in the case under study, the combustion chamber). The elimination of drives reduces the mass of the thrust vector control system, increases its reliability, and allows one to carry out its complete dynamic testing under terrestrial conditions because there is no need to rotate the engine during its operational development. The thrust vector control energy consumption (engine specific impulse loss) of the proposed system does not exceed that of an economy mechanical system (where the trust vector is controlled by engine rotation).

Keywords rocket engine; mechanical system; impulse force; gas-dynamic system; bifunctional thrust vector control system.

1 Degtyarev A. V. Sixty Years in Rocketry and Cosmonautics (in Russian). Dnipropetrovsk: ART-PRESS, 2014. $540 \mathrm{pp}$.

2 Igdalov I. M., Kuchma L. D., Polyakov N. V., Sheptun Yu. D. Dynamic Design of Rockets. Problems in the Dynamics of Rockets and Space Stages Thereof (in Russian). Dnipropetrovsk: Dnipropetrovsk National University, 2010. $254 \mathrm{pp}$.

3 Kolesnikov K. S. Rocket Dynamics (in Russian). Moscow, Mashinostroyeniye, 1980, 376 pp.

4 Kovalenko T. A., Sirotkina N. P., Kovalenko N. D. Bifunctional thrust-vector control system of launch vehicle space stage engine (in Russian). Teh. Meh. 2015. No. 1. Pp. 42-54.

5 Kovalenko N. D., Sheptun U. D., Kovalenko T. A., Strelnikov G. A. The new concept of thrust vector control for rocket engine. System Technologies. 2017. No. 6(107). Pp. 120-127.

6 Kovalenko T. A., Syrotkina N. P., Sheptun Yu. D. On the adaptation of bifunctional systems of liquidpropellant rocket thrust vector control to modern methods and systems of space rocket stage flight control. Teh. Meh. 2017. No. 3. Pp. 45-52.

7 Kovalenko N. D., Kovalenko T. O., Sheptun Yu. D. Separate control in response to launch vehicle stage motion parameter disturbances (in Russian). Proceedings of the VI ${ }^{\text {th }}$ Internatinal Conference "Space Technologies: the Present and the Future" (May 23-26, Dnipro, Ukraine). Dnipro: Yuzhnoye State Design Ofice, 2017. P. 39

8 Kovalenko N. D. Rocket Engine as a Rocket Flight Control Actuator (in Russian). Dnipropetrovsk: Institute of Technical Mechanics of the National Academy of Sciences of Ukraine and the National Space Agency of Ukraine, 2003. 412 pp.

9 Method for liquid-propellant rocket engine thrust vector control and liquid-propellant rocket engine for its implementation (in Ukrainian): Patent for Invention 103528 Ukraine: IPC F02K 9/00. No. 201114384; filed Dec. 5, 2011; published Oct. 25, 2013, Bul. No. 20.16 pp.

10 Liquid-propellant rocket engine thrust vector control system with turbine exhaust gas afterburning in the combustion chamber (in Ukrainian): Patent for Utility Model 94862 Ukraine, IPC 02 K 9/00. No. 2014 04258; filed Apr. 22, 2014; published Dec. 10, 2014, Bul. No. 23. 9 pp.

11 Method for liquid-propellant rocket engine thrust vector control and a liquid-propellant rocket engine for its implementation (in Ukrainian): Patent for Invention 105214 Ukraine: IPC F02K 9/56, F02K 9/82. No. 2011 12467; filed Oct. 24, 2011; published Apr. 25, 2014. Bul. No. 8.8 pp. 
12 Method for thrust vector control of a liquid-propellant rocket engine with a propellant component feeding turbopump assembly and a liquid-propellant rocket engine based thereon (in Ukrainian): Patent for Invention 107270 Ukraine: IPC F02 9/00. No. 2013 06211; filed May 20, 2013; published Dec. 10, 2014, Bul. No. 23. 11 pp.

Received on April 25, 2019,

in final form on June 12, 2019 